Proceedings

\title{
Polynuclear Silver(I) Complex with Thianthrene: Structural Characterization, Antimicrobial Activity and Interaction with Biomolecules ${ }^{+}$
}

\author{
Darko P. Ašanin 1,*, Tina P. Andrejević ${ }^{2}$, Sanja Skaro-Bogojevic ${ }^{3}$, Nevena Lj. Stevanović ${ }^{2}$, \\ Ivana Aleksic ${ }^{3}$, Dusan Milivojevic ${ }^{3}$, Franc Perdih ${ }^{4}$, Iztok Turel ${ }^{4}$, Miloš I. Djuran ${ }^{5}$ \\ and Biljana Đ. Glišić ${ }^{2}$ \\ 1 Department of Science, Institute for Information Technologies Kragujevac, University of Kragujevac, \\ Jovana Cvijića bb, 34000 Kragujevac, Serbia \\ 2 Department of Chemistry, Faculty of Science, University of Kragujevac, R. Domanovića 12, \\ 34000 Kragujevac, Serbia; tina.andrejevic@pmf.kg.ac.rs (T.P.A.); nevena.stevanovic@pmf.kg.ac.rs (N.L.S.); \\ biljana.glisic@pmf.kg.ac.rs (B.Đ.G.) \\ 3 Institute of Molecular Genetics and Genetic Engineering, University of Belgrade, Vojvode Stepe 444a, \\ 11042 Belgrade, Serbia; sanja.bogojevic@imgge.bg.ac.rs (S.S.-B.); ivana_aleksic@imgge.bg.ac.rs (I.A.); \\ dusan.milivojevic@imgge.bg.ac.rs (D.M.) \\ 4 Faculty of Chemistry and Chemical Technology, University of Ljubljana, Večna pot 113, SI-1000 Ljubljana, \\ Slovenia; franc.perdih@fkkt.uni-lj.si (F.P.); Iztok.Turel@fkkt.uni-lj.si (I.T.) \\ 5 Serbian Academy of Sciences and Arts, Knez Mihailova 35, 11000 Belgrade, Serbia; \\ milos.djuran@pmf.kg.ac.rs \\ * Correspondence: darko.asanin@uni.kg.ac.rs \\ + Presented at 1st International Electronic Conference on Applied Sciences, 10-30 November 2020; \\ Available online: https://asec2020.sciforum.net/.
}

Published: 9 November 2020

\begin{abstract}
New silver(I) complex with thianthrene (tia), $\left[\mathrm{Ag}\left(\mathrm{NO}_{3}\right)(\mathrm{tia})\left(\mathrm{H}_{2} \mathrm{O}\right)\right]_{n}$, was synthesized by the reaction of $\mathrm{AgNO}_{3}$ with an equimolar amount of tia in ethanol/dichloromethane (v/v 1:1) at room temperature, and characterized by NMR, IR and UV-Vis spectroscopy and single-crystal X-ray diffraction analysis. The antimicrobial activity of the synthesized complex was evaluated against the broad panel of Gram-positive and Gram-negative bacteria and Candida spp. This complex showed significant activity toward important human pathogens Gram-positive Staphylococcus aureus and Candida parapsilosis with minimal inhibitory concentrations (MICs) being $3.91 \mu \mathrm{g} / \mathrm{mL}$. The interaction of $\left[\mathrm{Ag}\left(\mathrm{NO}_{3}\right)(\mathrm{tia})\left(\mathrm{H}_{2} \mathrm{O}\right)\right]_{n}$ with calf thymus DNA (ct-DNA) and bovine serum albumin (BSA) was studied to evaluate the binding affinity towards these biomolecules for possible insights on the mode of antimicrobial activity. The binding affinity of the investigated complex to BSA is higher than that for DNA, indicating that proteins could be more favorable binding sites for this complex in comparison to the nucleic acids.
\end{abstract}

Keywords: silver(I) complexes; thianthrene; antimicrobial activity; DNA/BSA interaction

\section{Introduction}

Silver(I) complexes showed a wide range of applications in medicine as effective antiseptic, antibacterial and anti-inflammatory agents [1]. Antimicrobial properties of silver(I) complexes have been well known since the successful use of cream containing silver(I) sulfadiazine for the treatment of burn wounds [2]. The critical factor in determining the antimicrobial activity of silver(I) complexes is the type of the ligand donor atom bound to the $\mathrm{Ag}(\mathrm{I})$ ion. In this respect, in the last few decades, 
research has been focusing on the synthesis of silver(I) complexes with sulfur-donor ligands, including mercaptan, thioamide and thione ligands [3]. In the present contribution, the chemistry of new silver(I) complex with thianthrene (tia), $\left[\mathrm{Ag}\left(\mathrm{NO}_{3}\right)\left(\mathrm{H}_{2} \mathrm{O}\right)(\mathrm{tia})\right]_{n}$, is studied in solution and solid state using spectroscopic and crystallographic methods. This complex was evaluated for its antimicrobial activity against the panel of representative microorganisms, while its cytotoxicity was evaluated against normal human lung fibroblast cell line (MRC-5). Finally, the interaction of $\left[\mathrm{Ag}\left(\mathrm{NO}_{3}\right)\left(\mathrm{H}_{2} \mathrm{O}\right)(\mathrm{tia})\right]_{n}$ complex with biologically important molecules, BSA and DNA, was studied by different experimental techniques.

\section{Materials and Methods}

\subsection{Materials and Measurements}

All chemicals were of reagent-grade quality or higher and used without further purification. The silver(I) nitrate $\left(\mathrm{AgNO}_{3}\right)$, thianthrene (tia), ethanol, dichloromethane, acetonitrile, dimethyl sulfoxide (DMSO), deuterated dimethyl sulfoxide (DMSO- $\left.d_{6}\right)$ and chloroform $\left(\mathrm{CDCl}_{3}\right)$ were purchased from Sigma-Aldrich. Elemental microanalysis of the synthesized silver(I) complex for carbon, hydrogen and nitrogen were performed using a Perkin-Elmer 2400 Series II instrument $(\mathrm{CHN})$. The ${ }^{1} \mathrm{H}$ and ${ }^{13} \mathrm{C}$ NMR spectra were recorded at room temperature on a Varian Gemini 2000 spectrometer. The IR spectra were recorded as $\mathrm{KBr}$ pellets on a Perkin Elmer Spectrum 100 spectrometer over the wavenumber range of $4000-450 \mathrm{~cm}^{-1}$. The UV-Vis spectra were recorded over the wavelength range of 900-200 nm on a Shimadzu UV-1800 spectrophotometer. Molar conductivities were measured at room temperature on a digital conductivity-meter Crison Multimeter MM 41. The cyclic voltammetry (CV) measurements were performed using a potentiostat/galvanostat AutoLab PGSTAT204. The cell $(5.0 \mathrm{~mL})$ consisted of three electrode system, glassy carbon (GC) electrode as a working electrode, $\mathrm{Ag} / \mathrm{AgCl}$ (saturated $\mathrm{KCl}$ ) as a reference electrode and platinum wire as a counter electrode. X-ray diffraction data was collected on an Agilent Technologies SuperNova Dual diffractometer with Mo microfocus X-ray source $\left(\mathrm{K} \alpha\right.$ radiation, $\left.\lambda_{\mathrm{Mo}}=0.71073 \AA\right)$ with an Atlas detector at $150(2) \mathrm{K}$.

\subsection{Synthesis of Silver(I) Complex}

Silver(I) complex, $\left[\mathrm{Ag}\left(\mathrm{NO}_{3}\right)\left(\mathrm{H}_{2} \mathrm{O}\right)(\right.$ tia $\left.)\right] n$, was synthesized according to the modified procedure for the preparation of silver(I) complexes with phthalazine and quinazoline [4]. The solution of 1.0 mmol of the silver(I) nitrate $\left(169.9 \mathrm{mg}\right.$ of $\left.\mathrm{AgNO}_{3}\right)$ in $5.0 \mathrm{~mL}$ of ethanol was added slowly under stirring to the solution containing an equimolar amount of tia $(216.3 \mathrm{mg})$ in $5.0 \mathrm{~mL}$ of dichloromethane. The reaction mixture was stirred for $3 \mathrm{~h}$ in dark at room temperature. The obtained solution was left at room temperature, and after several days, colorless crystals of silver(I) complex were formed. These crystals were filtered off and dried in the dark at ambient temperature. Yield: $315.3 \mathrm{mg}(78 \%)$.

Anal. calcd for $\left[\mathrm{Ag}\left(\mathrm{NO}_{3}\right)(\mathrm{tia})\left(\mathrm{H}_{2} \mathrm{O}\right)\right]_{n}=\mathrm{C}_{12} \mathrm{H}_{10} \mathrm{AgNO}_{4} \mathrm{~S}_{2}(\mathrm{MW}=404.21): \mathrm{C}, 35.66 ; \mathrm{H}, 2.49 ; \mathrm{N}, 3.47$. Found: $\mathrm{C}, 35.39 ; \mathrm{H}, 2.48 ; \mathrm{N}, 3.32 \% .{ }^{1} \mathrm{H}$ NMR $\left(200 \mathrm{MHz}, \mathrm{CDCl}_{3}\right): \delta=7.48(d d, J=3.3,2.3 \mathrm{~Hz}, \mathrm{H} 1, \mathrm{H} 4, \mathrm{H} 5$ and H8), $7.23 \mathrm{ppm}(d d, J=3.1,2.4 \mathrm{~Hz}, \mathrm{H} 2, \mathrm{H} 3, \mathrm{H} 6$ and $\left.\mathrm{H} 7) .{ }^{13} \mathrm{C} \mathrm{NMR} \mathrm{(50} \mathrm{MHz,} \mathrm{CDCl} 3\right): \delta=127.6(\mathrm{Cla}$, C4a, C5a and C8a), 128.6 (C1, C4, C5 and C8), 135.6 ppm (C2, C3, C6 and C7). IR (KBr, v, cm $\left.{ }^{-1}\right)$ : 3435s $(v(\mathrm{O}-\mathrm{H})), 3042 \mathrm{w}, 2927 \mathrm{w}(v(\mathrm{Car}-\mathrm{H})), 1438 \mathrm{~s}, 1431 \mathrm{~s}\left(v\left(\mathrm{Car}_{\mathrm{ar}}=\mathrm{Car}\right)\right), 1384 \mathrm{vs}\left(\mathrm{Vas}_{\mathrm{as}}\left(\mathrm{NO}_{3}\right)\right), 761 \mathrm{~s}, 750 \mathrm{~s}\left(\gamma\left(\mathrm{Car}_{\mathrm{a}} \mathrm{H}\right)\right)$. UV-Vis (DMSO, $\left.\lambda_{\max }, \mathrm{nm}\right): 259.0\left(\varepsilon=6.7 \cdot 10^{4} \mathrm{M}^{-1} \mathrm{~cm}^{-1}\right) . \Lambda_{\mathrm{M}}(\mathrm{DMSO}): 45.3 \Omega^{-1} \mathrm{~cm}^{2} \mathrm{~mol}^{-1}$.

\subsection{Antimicrobial Susceptibility Testing}

According to the standard broth microdilution assays, recommended by the National Committee for Clinical Laboratory Standards (M07-A8) for bacteria and Standards of European Committee on Antimicrobial Susceptibility Testing (v 7.3.1: Method for the determination of broth dilution minimum inhibitory concentrations of antifungal agents for yeasts) for Candida spp., MIC (minimal inhibitory concentration) values of silver complex and corresponding ligand were determined. The tested compounds were dissolved in DMSO at concentration of $50 \mathrm{mg} / \mathrm{mL}$, and the highest tested concentration was $200 \mu \mathrm{g} / \mathrm{mL}$ used on bacteria species: Staphylococcus aureus ATCC 
25923, Listeria monocytogenes NCTC 11994 and Escherichia coli NCTC 9001, and $250 \mu \mathrm{g} / \mathrm{mL}$ used on Candida strains (C. albicans ATCC 10231 and C. parapsilosis ATCC 22019). The inoculums were $5 \cdot 10^{5}$ colony forming units, cfu $/ \mathrm{mL}$, for bacteria and $1 \cdot 10^{5} \mathrm{cfu} / \mathrm{mL}$ for Candida species. The MIC value was recorded as the lowest concentration that inhibited the growth after $24 \mathrm{~h}$ incubation at $37^{\circ} \mathrm{C}$, using the Tecan Infinite 200 PRO multiplate reader (Tecan Group Ltd., Männedorf, Switzerland).

\subsection{In Vitro Cytotoxicity}

Antiproliferative activity assay (MTT) with 3-(4,5-dimethylthiazol-2-yl)-2,5-diphenyltetrazolium bromide was tested on a human lung fibroblast cell line (MRC-5) using compounds with MICs of up to $50 \mu \mathrm{g} / \mathrm{mL}$ [5]. MRC- 5 cells were plated in a 96-well flat-bottom plate at a concentration of $1 \cdot 10^{4}$ cells per well in RPMI 1640 medium supplemented with $100 \mu \mathrm{g} / \mathrm{mL}$ streptomycin, $100 \mathrm{U} / \mathrm{mL}$ penicillin, and $10 \%(\mathrm{v} / \mathrm{v})$ FBS. Cells were grown in humidified atmosphere of $95 \%$ air and $5 \% \mathrm{CO}_{2}$ at $37{ }^{\circ} \mathrm{C}$, and after $48 \mathrm{~h}$, the extent of MTT reduction was measured spectrophotometrically at $540.0 \mathrm{~nm}$ using a Tecan Infinite 200 PRO multiplate reader (Tecan Group Ltd., Männedorf, Switzerland). Cytotoxicity was expressed as the concentration of the compound inhibiting cell growth by $50 \%$ (IC50) in comparison to control (DMSO-treated cells).

\subsection{Protein Binding Study}

A stock solution of BSA (bovine serum albumin) was prepared in PBS (phosphate-buffered saline) buffer. Fluorescence titration experiments were carried out by keeping the concentration of BSA constant $(16 \mu \mathrm{M})$, while varying the concentration of silver(I) complex $(0-65 \mu \mathrm{M})$ at ambient temperature upon excitation wavelength at $275.0 \mathrm{~nm}$, at the range of $280.0-500.0 \mathrm{~nm}$.

\subsection{Partition Coefficient $(\log P)$}

Partition coefficient $(\log P)$ between octanol and water was determined using the flask-shaking method [6]. The synthesized complex was dissolved in DMSO and added to water/octanol system. The mixture was vortexed for $1 \mathrm{~h}$ at room temperature to allow partitioning. After that time, the aqueous layer was separated from the octanol layer. The concentration of complex in the two phases was determined by measuring absorbance values using previously determined calibration curves.

\subsection{DNA Binding Study}

The competitive binding experiments were carried out in the buffer ( $\mathrm{pH}$ 7.4) by maintaining the ethidium bromide (EthBr) and ct-DNA concentration at 10 and $100 \mu \mathrm{M}$, respectively, while increasing the concentration of the complex $(0-165 \mu \mathrm{M})$. Each sample solution was scanned in the wavelength range 525.0-800.0 nm with an excitation wavelength of $520.0 \mathrm{~nm}$. Before measurement, sample solution was shaken and incubated at room temperature for $5 \mathrm{~min}$. The DNA interaction of complex was additionally investigated by cyclic voltammetry using the same three electrode system described above by maintaining the complex concentration constant, while increasing the concentration of DNA $(0-90 \mu \mathrm{M})$.

\section{Results and Discussion}

\subsection{Synthesis and Structural Characterization}

Silver(I) complex, $\left[\mathrm{Ag}\left(\mathrm{NO}_{3}\right)\left(\mathrm{H}_{2} \mathrm{O}\right)(\text { tia })\right]_{n}$, was synthesized according to the procedure presented in Figure 1. Spectroscopic ( ${ }^{1} \mathrm{H}$ and ${ }^{13} \mathrm{C}$ NMR, IR and UV-Vis), electrochemical (cyclic voltammetry) and crystallographic (single-crystal X-ray diffraction analysis) methods were applied for the characterization of the synthesized complex. From the obtained data, it can be concluded that in the silver(I) complex, tia acts as a bridging ligand connecting two $\mathrm{Ag}(\mathrm{I})$ ions. In the solid state, the complex has polynuclear structure, with tetrahedrally coordinated $\mathrm{Ag}(\mathrm{I})$ ion via two thianthrene sulfur atoms, one nitrate oxygen and one water oxygen atoms. The ORTEP drawing of $\left[\mathrm{Ag}\left(\mathrm{NO}_{3}\right)\left(\mathrm{H}_{2} \mathrm{O}\right)(\mathrm{tia})\right]_{n}$ complex was also shown in Figure 1. 
As revealed by NMR spectroscopy, tia ligand remains coordinated to $\mathrm{Ag}(\mathrm{I})$ ion for at least $48 \mathrm{~h}$ in DMSO, while the conductivity measurements of the complex in the same solvent showed very fast release of the coordinated nitrate from the coordination sphere of $\mathrm{Ag}(\mathrm{I})$ ion (vide supra) [7].

(a)

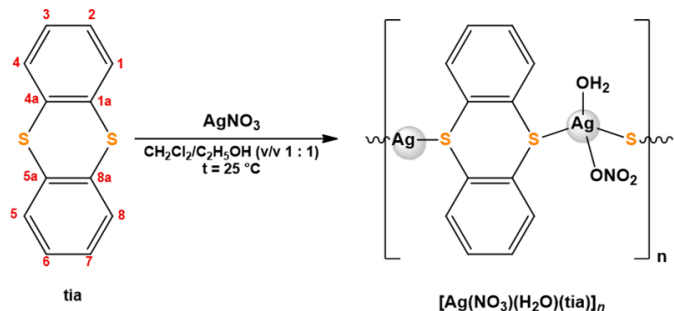

(b)

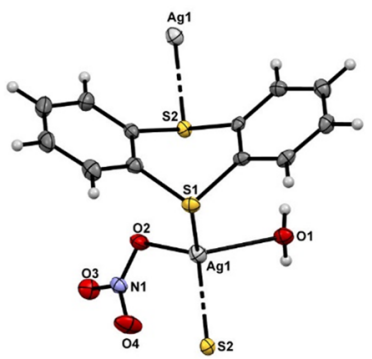

Figure 1. (a) Schematic presentation of the synthetic route and (b) ORTEP drawing of silver(I) complex with thianthrene (tia), $\left[\mathrm{Ag}\left(\mathrm{NO}_{3}\right)\left(\mathrm{H}_{2} \mathrm{O}\right)(\mathrm{tia})\right]_{n}$ complex.

\subsection{Antimicrobial Activity}

While thianthrene was not affecting the growth of the tested microorganisms, $\left[\mathrm{Ag}\left(\mathrm{NO}_{3}\right)\left(\mathrm{H}_{2} \mathrm{O}\right)(\mathrm{tia})\right]_{n}$ complex showed the highest potency against $C$. parapsilosis ATCC 22019 and $S$. aureus ATCC 25923 with MIC values of $3.91 \mu \mathrm{g} / \mathrm{mL}$ (Table 1). Nevertheless, these values were almost the same as the IC 50 value against MRC-5 cells, indicating the high cytotoxicity of the complex. Considerable activity was also observed in the case of other tested microorganisms (Table 1).

Table 1. Antimicrobial activity of silver(I) complex and the corresponding thianthrene ligand expressed as MIC $(\mu \mathrm{g} / \mathrm{mL})$ in comparison to their cytotoxicity against healthy human fibroblasts MRC-5 (IC50, $\mu \mathrm{g} / \mathrm{mL})$.

\begin{tabular}{ccc}
\hline Tested Organisms & {$\left[\mathbf{A g}\left(\mathbf{N O}_{3}\right)(\mathbf{t i a})\left(\mathbf{H}_{2} \mathbf{O}\right)\right]_{n}$} & thianthrene \\
\hline C. albicans ATCC 10231 & 7.81 & $>200$ \\
C. parapsilosis ATCC 22019 & 3.91 & $>200$ \\
S. aureus ATCC 25923 & 3.91 & $>250$ \\
L. monocytogenes NCTC 11994 & 15.62 & $>250$ \\
E. coli NCTC9001 & 15.62 & $>250$ \\
\hline MRC-5 cells & 4.25 & $>100$ \\
\hline
\end{tabular}

\subsection{BSA Binding Study}

Serum albumin is a protein in the blood plasma, which plays a crucial role in the transport and metabolism of pharmacologically active compounds [8]. The affinity of $\left[\mathrm{Ag}\left(\mathrm{NO}_{3}\right)\left(\mathrm{H}_{2} \mathrm{O}\right)(\mathrm{tia})\right]_{n}$ complex to BSA was studied using florescence quenching experiments. As can be seen from Figure 2, BSA exhibits very intensive fluorescence at $365.0 \mathrm{~nm}$, with intensity significantly decreasing upon addition of the studied complex $(0-65 \mu \mathrm{M})$. This can be the consequence of the complex binding to this biomolecule, resulting in the changes of its tertiary structure [8]. The data obtained by using Stern-Volmer and Scatchard equations (Stern-Volmer constants $\left(K_{s v}\right)$, quenching rate constants $\left(K_{q}\right)$, binding constants $\left(K_{A}\right)$ and number of binding sites per BSA $\left.(n)\right)$ are also presented in Figure 2 . The $K_{q}$ value indicates that the investigated silver(I) complex shows good quenching ability of the BSA 
fluorescence $\left(K_{q} \sim 10^{13} \mathrm{M}^{-1} \mathrm{~S}^{-1}\right)$, being higher than the corresponding values of bimolecular dynamic quenchers $\left(2 \cdot 10^{10} \mathrm{M}^{-1} \mathrm{~S}^{-1}\right)$.

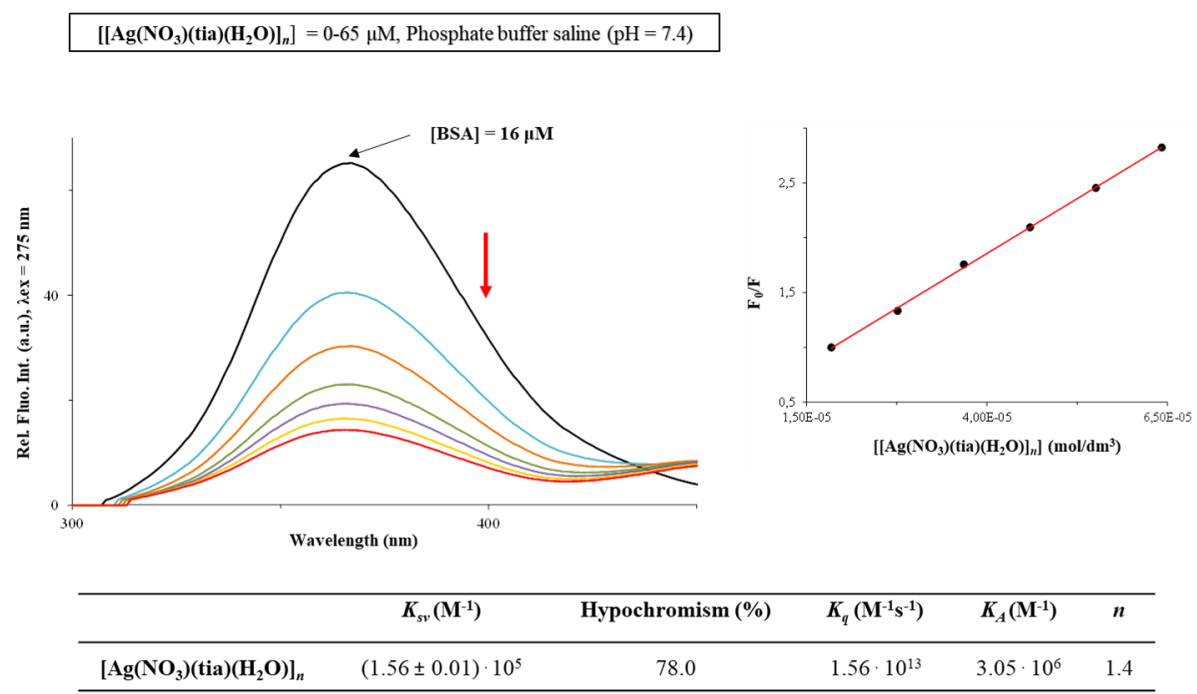

Figure 2. Fluorescence emission spectra of BSA in the presence of an increasing concentration of $\left[\mathrm{Ag}\left(\mathrm{NO}_{3}\right)\left(\mathrm{H}_{2} \mathrm{O}\right)(\text { tia) })\right]_{n}$ complex alongside the values of the binding constants. Arrow shows the intensity changes upon increased amount of the complex. Inserted graph: Stern-Volmer plot of $\mathrm{F}_{0} / \mathrm{F}$ vs. $\left[\mathrm{Ag}\left(\mathrm{NO}_{3}\right)\left(\mathrm{H}_{2} \mathrm{O}\right)(\text { tia })\right]_{n}$ complex.

\subsection{Partition Coefficients $(\log P)$}

Lipophilicity of a compound can be connected with its cellular uptake efficiency, which is of great importance in the new drug candidates' design [9]. Octanol-water partition coefficient $(\log P)$, which is a measure of lipophilicity, for $\left[\mathrm{Ag}\left(\mathrm{NO}_{3}\right)\left(\mathrm{H}_{2} \mathrm{O}\right)(\text { tia })\right]_{n}$ complex, is found to be 0.72 , indicating its hydrophobic properties. This value is in accordance with $\log P$ values of new pharmacophores in the Comprehensive Medicinal Chemistry database being in range from -0.4 to 5.6 [10].

\subsection{DNA Binding Study}

Mechanism of antimicrobial activity of silver(I) complexes can be related to their interaction with DNA [1]. In the present study, fluorescence spectroscopy and cyclic voltammetry were used for investigation of DNA interaction of $\left[\mathrm{Ag}\left(\mathrm{NO}_{3}\right)\left(\mathrm{H}_{2} \mathrm{O}\right) \text { (tia) }\right]_{n}$ complex. The emission spectra of EthBrDNA system in the absence and presence of the investigated complex are presented in Figure 3, including the plot of $\mathrm{F}_{0} / \mathrm{F}$ versus [complex] ( $\mathrm{F}_{0}$ and $\mathrm{F}$ are the fluorescence intensities in the absence and presence of the complex, respectively). As can be seen, addition of the silver(I) complex to the EthBr-DNA solution caused decrease in the fluorescence intensity. This can be a consequence of the complex binding to DNA, leading to the formation of a non-fluorescence EthBr-DNA-complex system [11]. 

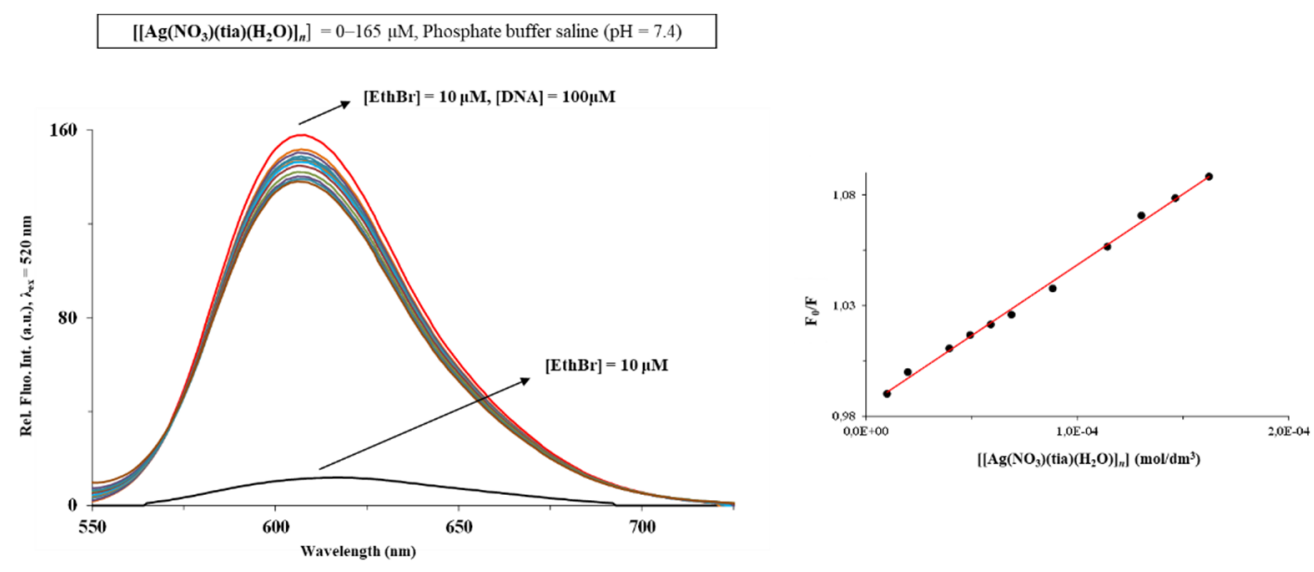

Figure 3. Fluorescence emission spectra of EthBr-DNA system in the presence of an increasing concentration of $\left[\mathrm{Ag}\left(\mathrm{NO}_{3}\right)\left(\mathrm{H}_{2} \mathrm{O}\right)(\text { tia) }]_{n}\right.$ complex. Inserted graph: Stern-Volmer plot of $\mathrm{F}_{0} / \mathrm{F}$ vs. [complex].

From the $K_{s v}$ value of $6.49 \cdot 10^{2} \mathrm{M}^{-1}$, it can be concluded that the presently investigated complex binds to DNA through the non-intercalative (electrostatic) mode. This mode of DNA interaction could be proposed from the results obtained from electrochemical measurements.

\section{Conclusions}

The present study confirms that the sulfur-containing ligand, thianthrene (tia), is an effective bridging ligand between two $\mathrm{Ag}(\mathrm{I})$ ions forming polynuclear $\left[\mathrm{Ag}\left(\mathrm{NO}_{3}\right)\left(\mathrm{H}_{2} \mathrm{O}\right)(\mathrm{tia})\right]_{n}$ complex. This complex shows considerable activity against two different Candida spp. and three bacterial species, being the most active toward Staphylococcus aureus and Candida parapsilosis. BSA could transport the silver(I) complex to the infected cells, and inside the cell, this complex could exert its antimicrobial activity through interaction with DNA.

Author Contributions: Conceptualization, D.P.A. and B.Đ.G.; investigation, D.P.A., T.P.A., S.S.-B., N.L.S., I.A., D.M. and F.P.; resources, I.T. and M.I.D.; writing-original draft preparation, D.P.A., T.P.A., S.S.-B. and F.P.; writing-I.T., M.I.D. and B.Đ.G., visualization, T.P.A., N.L.S. and D.M.; supervision, I.T., M.I.D. and B.Đ.G. All authors have read and agreed to the published version of the manuscript.

Funding: This research has been financially supported by the Ministry of Education, Science and Technological Development of the Republic of Serbia (agreement number 451-03-68/2020-14/200042, 451-03-68/202014/200122 and 451-03-68/2020-14/200378) and by the Slovenian Research Agency (grant number P1-0175). The EN $\rightarrow$ FIST Centre of Excellence, Trg Osvobodilne fronte 13, SI-1000 Ljubljana, Slovenia, is acknowledged for the use of the SuperNova diffractometer. This research has also received funding from the Serbian Academy of Sciences and Arts under strategic projects programme-grant agreement number 01-2019-F65, and project of this institution number F128.

Conflicts of Interest: The authors declare no conflict of interest.

\section{References}

1. Medici, S.; Peana, M.F.; Nurchi, V.M.; Zoroddu, M.A. Medical uses of silver: History, myths, and scientific evidence. J. Med. Chem. 2019, 62, 5923-5943.

2. Klasen, H.J. Historical review of the use of silver in the treatment of burns. I. Early uses. Burns 2000, 26, 117-130.

3. Varna, D.; Zainuddin, D.I.; Hatzidimitriou, A.G.; Psomas, G.; Pantazaki, A.A.; Papi, R.; Angaridis, P.; Aslanidis, P. Homoleptic and heteroleptic silver(I) complexes bearing diphosphane and thioamide ligands: Synthesis, structures, DNA interactions and antibacterial activity studies. Mater. Sci. Eng. C 2019, 99, 450-459. 
4. Glišić, B.Đ.; Senerovic, L.; Comba, P.; Wadepohl, H.; Veselinovic, A.; Milivojevic, D.R.; Djuran, M.I.; Nikodinovic-Runic, J. Silver(I) complexes with phthalazine and quinazoline as effective agents against pathogenic Pseudomonas aeruginosa strains. J. Inorg. Biochem. 2016, 155, 115-128.

5. Hansen, M.B.; Nielsen, S.E.; Berg, K. Re-examination and further development of a precise and rapid dye method for measuring cell growth/cell kill. J. Immunol. Methods 1989, 119, 203-210.

6. Puckett, C.A.; Barton, J.K. Methods to explore cellular uptake of ruthenium complexes. J. Am. Chem. Soc. 2007, 129, 46-47.

7. Ali, I.; Wani, W.A.; Saleem, K. Empirical formulae to molecular structures of metal complexes by molar conductance, Synth. React. Inorg. Met. 2013, 43, 1162-1170.

8. Johansson, J.S. Binding of the volatile anesthetic chloroform to albumin demonstrated using tryptophan fluorescence quenching. J. Biol. Chem. 1997, 272, 17961-17965.

9. Li, J.J.; Tian, M.; Tian, Z.; Zhang, S.; Yan, C.; Shao, C.; Liu, Z. Half-sandwich iridium(III) and ruthenium(II) complexes containing $\mathrm{P}^{\wedge} \mathrm{P}$-chelating ligands: A new class of potent anticancer agents with unusual redox features. Inorg. Chem. 2018, 57, 1705-1716.

10. Ghose, A.K.; Viswanadhan, V.N.; Wendoloski, J.J. A knowledge-based approach in designing combinatorial or medicinal chemistry libraries for drug discovery. 1. A qualitative and quantitative characterization of known drug databases. J. Comb. Chem. 1999, 1, 55-68.

11. Shi, Y.; Guo, C.; Sun, Y.; Liu, Z.; Xu, F.; Zhang, Y.; Wen, Z.; Li, Z. Interaction between DNA and microcystinLR studied by spectra analysis and atomic force microscopy. Biomacromolecules 2011, 12, 797-803.

Publisher's Note: MDPI stays neutral with regard to jurisdictional claims in published maps and institutional affiliations.

(C) 2020 by the authors. Licensee MDPI, Basel, Switzerland. This article is an open access article distributed under the terms and conditions of the Creative Commons Attribution (CC BY) license (http://creativecommons.org/licenses/by/4.0/). 